\title{
PERAN BALAI PEMASYARAKATAN DALAM BIMBINGAN KLIEN NARKOBA GUNA MENCEGAH PENGULANGAN KEJAHATAN NARKOBA
}

\author{
Sucipto, Hidayatullah dan Iskandar Wibawa
}

Email : suciptopas@gmail.com, hidayatullah@umk.ac.id, iskandar.wibawa@yahoo.com

Fakultas Hukum Universitas Muria Kudus

\begin{abstract}
ABSTRAK
Pembinaan dan bimbingan kepada klien oleh Balai Pemasyarakatan sangat penting dalam mendukung program Pemerintah dalam mengurangi tindak kejahatan, khususnya tindak pidana narkotika. Pembinaan dan bimbingan kepada klien narkoba oleh Bapas saat ini hanya diberikan bagi klien yang mengajukan Pembebasan Bersyarat, Cuti Menjelang Bebas dan Cuti Bersyarat. Tujuan dari pembinaan dan bimbingan tersebut adalah setelah narapidana bebas atau keluar dari Lembaga Pemasyarakatan mempunyai keahlian dan yang terpenting yaitu tidak melakukan kejahatan kembali. Penelitian ini termasuk dalam tipe penelitian deskriptif analitis dengan metode pendekatan yuridis empiris untuk melihat secara lengkap permasalahan penelitian yang bersumber dari data primer dan data sekunder. Pengambilan data dilakukan dengan cara studi lapangan (wawancara) dan studi kepustakaan, data yang diperoleh dianalisis secara kualitatif dan disajikan dalam bentuk deskriptif. Hasil penelitian ini diketahui bahwa klien narkoba di Balai Pemasyarakatan Pati pada tahun 2016 jumlahnya adalah 61 orang, terdiri dari 59 laki-laki dan 2 perempuan. Pada tahun 2017 jumlah narapidana binaan di Bapas Pati jumlahnya ada 78 Narapidana, yang terdiri dari 72 laki-laki dan 6 perempuan, dengan demikian jumlah narapidana di Bapas Pati dari tahun 2016 ke tahun 2017 mengalami peningkatan. Peran Bapas sangat strategis dalam membina dan membimbing narapidana, karena Bapas mempunyai tanggungjawab yang besar, yaitu mendidik dan membina narapidana untuk menjadi pribadi yang lebih baik dan dapat diterima kembali di masyarakat. Kendala-kendala yang muncul dalam melakukan bimbingan terhadap klien narkoba di Balai Pemasyarakatan (BAPAS) Pati, antara lain terbatasnya petugas di Bapas Pati, minimnya anggaran, masih adanya klien yang kurang bersungguh-sungguh dalam mengikuti bimbingan dan pembinaan serta sarana dan prasarana di Bapas Pati yang kurang. Konsep pembimbingan yang baik bagi klien di masa mendatang, bagi klien warga binaan pada umumnya dan klien warga binaan kasus narkoba pada khususnya yaitu dengan membimbing warga binaan dari awal, yaitu dari sejak warga binaan masuk ke Rutan atau Lapas.
\end{abstract}

Kata Kunci : Peran Balai Pemasyarakatan, Bimbingan, Klien Narkoba 


\section{PENDAHULUAN}

Peredaran narkoba selama ini sangat meresahkan masyarakat kejahatan, korbannya tidak hanya orang dewasa dan remaja bahkan juga anakanak usia produktif. Upaya Pemerintah dalam memberantas peredaran narkoba dan penyalahgunaan narkotika, yaitu dengan mengeluarkan Undang-Undang Nomor 35 Tahun 2009 tentang Narkotika (selanjutnya ditulis UU Narkotika). Ancaman hukuman dalam UU Narkotika sebagaimana diatur Pasal 132 angka 3 maksimal hukuman mati dan hukuman minimal 1 (satu) tahun. ${ }^{28}$

Berlakunya UU Narkotika seakan tidak membuat efek jera bagi pengedar dan pelaku penyalahgunaan narkotika. Guna menekan angka peredaran narkoba dan menekan jumlah pemakai narkoba, maka narapidana narkoba yang akan menjelang Cuti Bersyarat, Cuti Menjelang Bebas dan Pembebasan Bersyarat, dilakukan pembinaan dan bimbingan oleh Bapas, tujuannya supaya narapidana tersebut tidak mengulangi perbuatannya yang sama di kemudian hari. ${ }^{29}$

Dalam Lembaga Pemasyarakatan (LP) narapidana dibina dengan tujuan setelah keluar dari Lembaga Pemasyarakatan tidak melakukan kejahatan kembali. Dalam membina narapidana peran Bapas (Balai Pemasyarakatan), salah satu narapidana yang dibina oleh Bapas adalah narapidana tindak pidana narkotika. Peredaran narkotika di Indonesia perkembangannya sangat pesat, khususnya dalam hal ini peredaran narkotika di kota Pati. Jumlah klien

\footnotetext{
28 Andi Hamzah, Asas Asas Hukum Pidana, Rineka Cipta, 2008, Jakarta, hlm. 15

${ }_{29}$ Abdul Djamali, Pengantar Hukum Indonesia, Raja Grafindo Persada, Jakarta, 1990, hlm.45
}

narkoba yang dibina Bapas dapat dilihat dari pada tabel dibawah ini:

Table 1

Jumlah Klien Narkoba Binaan Bapas

Pati Tahun 2016 dan 2017

\begin{tabular}{|l|l|c|l|}
\hline Tahun & $\begin{array}{l}\text { Laki- } \\
\text { Laki }\end{array}$ & Perempuan & Jumlah \\
\hline 2016 & 59 & 2 & 61 \\
\hline 2017 & 72 & 6 & 78 \\
\hline
\end{tabular}

Sumber : Balai Pemasyarakatan Pati Tahun 2016 dan tahun 2017

Data pada tahun 2016 total ada 61 narapidana (laki-laki dan perempuan) dan 2017 ada 78 narapidana (laki-laki dan perempuan), data di atas menunjukkan bahwa ada peningkatan jumlah narapidana narkotika yang dibina dan dibimbing Bapas Pati. Adanya peningkatan sebagaimana tersebut di atas, maka Bapas Pati harus mempunyai konsep yang jelas agar pembinaan dan bimbingan dapat berjalan dengan baik dengan hasil yang maksimal, sehingga narapidana yang sudah bebas tidak mengulangi perbuatan yang sama (residivis) di kemudian hari.

Dalam pembinaan Tahap awal dimulai sejak yang bersangkutan berstatus sebagai Narapidana sampai dengan 1/3 (satu per tiga) dari masa pidana (Pasal 9 angka 1 PP No. 31 Tahun 1999), dan untuk tahap lanjutan sebagaimana diatur Pasal 9 angka 2 PP No. 31 Tahun 1999, meliputi :

a. Tahap lanjutan pertama, sejak berakhirnya pembinaan tahap awal sampai dengan $1 / 2$ (satu per dua) dari masa pidana; dan

b. Tahap lanjutan kedua, sejak berakhirnya pembinaan tahap lanjutan pertama sampai dengan 2/3 (dua per tiga) masa pidana. 
Pembinaan tahap akhir dilaksanakan sejak berakhirnya tahap lanjutan sampai dengan berakhirnya masa pidana dari narapidana yang bersangkutan (Pasal 9 angka 3 PP No. 31 Tahun 1999).

Narapidana juga manusia yang harus dianggap ada keberadaanya, narapidana perlu dibina dan dibimbing supaya setelah keluar narapidana dapat mandiri dan berkarya di tengah-tengah masyarakat, memang tidak mudah dalam membina dan membimbing narapidana, dalam hal ini membimbing dan membina narapidana narkotika, pasti ada hambatan dan kendalakendala, peran Bapas dalam mambina dan membimbing narapidana sangat penting. Tujuan dari pembinaan dan bimbingan yaitu supaya narapidana tidak melakukan perbuatan-perbuatan yang melanggar hukum (tidak mengulangi perbuatan yang sama dengan sebelumnya).

Berdasarkan latar belakang sebagaimana tersebut di atas, maka penulis tertarik untuk mengadakan penelitian dengan judul "Peran Balai Pemasyarakatan Dalam Bimbingan Klien Narkoba Guna Mencegah Pengulangan Kejahatan Narkoba (Studi Kasus di Balai Pemasyarakatan Pati)".

Berdasarkan latar belakang sebagaimana diuraikan di atas, maka permasalahan yang akan diteliti dalam penelitian ini yaitu sebagai berikut:
1. Bagaimana
peran
Balai
Pemasyarakatan (BAPAS) Pati dalam membimbing klien narkoba berjalan dengan efektif ?

2. Bagaimana kendala-kendala yang muncul dalam melakukan bimbingan terhadap klien narkoba di Balai Pemasyarakatan (BAPAS) Pati ?
3. Bagaimana konsep pembimbingan yang baik bagi klien narkoba di masa mendatang ?

\section{METODE PENELITIAN}

Pendekatan masalah dalam penelitian ini, yaitu yuridis empiris. Penelitian yuridis empiris menurut Dyah Ochtorina Susanti dan A'an Efendi yaitu penelitian hukum sosiologis/empiris meliputi penelitian terhadap identifikasi hukum (hukum tidak tertulis) dan penelitian terhadap efektifitas hukum. ${ }^{30}$ Penelitian empiris ini mencakup identifikasi hukum dan efektivitas penerapan hukum dalam masyarakat dan juga mempelajari aturan-aturan hukum yang berkaitan dengan objek yang diteliti, yaitu peran Balai Pemasyarakatan (BAPAS) dalam membimbing klien narkoba. ${ }^{31}$

Dalam upaya untuk memperoleh data yang akurat, diperlukan langkahlangkah serta teknik yang tepat. Sesuai dengan metode pendekatan yang digunakan, yaitu yuridis empiris, maka data utamanya adalah data primer dan data sekunder sebagai data pendukung. Data primer diperoleh dengan melakukan studi lapangan, sedangkan data sekunder diperoleh dengan melakukan studi kepustakaan. ${ }^{32}$

Berdasarkan metode pendekatan yang digunakan dalam penelitian ini maka metode analisis data yang digunakan yaitu analisis kualitatif.

\footnotetext{
${ }^{30}$ Dyah Ochtorina Susanti dan A'an Efendi, Penelitian Hukum (Legal Research) ,Sinar Grafika, Jakarta, 2014, hlm. 18.

${ }^{31}$ H. Zainuddin Ali, Metode Penelitian hukum, Sinar Grafika, 2010, Jakarta, hlm.10

${ }^{32}$ Bambang Sunggono, Metodologi Penelitian Hukum Cetakan ke-14, Rajawali Pers, Jakarta, $\mathrm{hlm} .3$
} 


\section{HASIL PENELITIAN DAN}

\section{PEMBAHASAN}

1. Peran Balai Pemasyarakatan (BAPAS) Pati Dalam Membimbing dan Pembinaan Terhadap Klien Narkoba

Pembinaan terhadap klien menurut

Pasal 1 ayat (5) Peraturan Pemerintah Nomor 32 Tahun 1999 tentang Syarat Dan Tata Cara Pelaksanaan Hak Warga Binaan Pemasyarakatan adalah pemberian tuntunan untuk meningkatkan kualitas ketaqwaan terhadap Tuhan Yang Maha Esa, intelektual, sikap dan perilaku, profesional, kesehatan jasmani dan rohani Klien Pemasyarakatan. Pembinaan menurut Pasal 1 ayat (2) Peraturan Pemerintah Nomor 32 Tahun 1999 adalah kegiatan untuk meningkatkan kualitas ketaqwaan kepada Tuhan Yang Maha Esa, intelektual, sikap dan perilaku, profesional, kesehatan jasmani dan rohani Narapidana dan Anak Didik Pemasyarakatan.

Pengertian sebagaimana tersebut di atas dapat dijelaskan bahwa fungsi pembimbingan dan pembinaan bagi narapidana yang dilakukan oleh BAPAS merupakan upaya dalam memberikan tuntunan dengan tujuan untuk meningkatkan kualitas ketaqwaan terhadap Tuhan Yang Maha Esa, kesadaran berbangsa dan bernegara, intelektual, sikap dan perilaku, kesehatan jasmani dan rohani, kesadaran hukum, reintegrasi sehat dengan masyarakat, keterampilan kerja serta latihan kerja dan produksi, sehingga setelah narapidana bebas nanti mempunyai keterampilan yang dapat dijadikan sebagai modal kerja dan tidak melakukan tindak pidana lagi.

Pada umumnya pembinaan dan bimbingan diprioritaskan bagi narapidana bersyarat, cuti bersyarat dan bagi narapidana cuti menjelang bebas. Syarat-syarat narapidana pembebasan bersyarat, cuti bersyarat dan bagi narapidana cuti menjelang bebas diatur dalam Peraturan Menteri Hukum Dan Hak Asasi Manusia Repubik Indonesia Nomor M.2.Pk.04-10 Tahun 2007 tentang Syarat Dan Tata Cara Pelaksanaan Asimilasi, Pembebasan Bersyarat, Cuti Menjelang Bebas, dan Cuti Bersyarat.

Bambang Sulistyo selaku Plt Kepala Bapas Pati memberikan penjelasan bahwa pada Pasal 10 Keputusan Direktur Jendral Pemasyarakatan Nomor E.06-PK.04.10 Tahun 1992 Tentang Petunjuk Pelaksanaan Asimilasi, Pembebasan Bersyarat dan Cuti Menjelang Bebas, menyatakan bahwa $:^{33}$

1. Pelaksanaan Pembebasan Bersyarat narapidana adalah Jaksa pada Kejaksaan Negeri di wilayah hukum Lembaga Pemasyarakatan tempat narapidana yang bersangkutan menjalani pidana:

2. Apabila narapidana menjalankan masa pembebasan bersyarat bukan di wilayah hukum jaksa yang melaksanakan, maka dalam jangka waktu 7 hari setelah tanggal pelaksanaan, narapidana tersebut harus melapor ke Kejaksaan Negeri di tempat ia menjalani masa pembebasan bersyaratnya dengan memperlihatkan buku bebas bersyarat yang diterimanya dan diantar oleh petugas Balai Bimbingan Kemasyarakatan dan Pengentasan Anak;

33 Bambang Sulistyo, wawancara pribadi, Kasubsi Bimbingan Klien Dewasa Bapas Pati, tanggal 15 Agustus 2018 
3. Narapidana yang akan melaksanakan pembebasan bersyarat diserahterimakan oleh Kepala Lembaga Pemasyarakatan kepada Kepala Balai Bimbingan Kemasyarakatan dan pengentasan Anak yang akan memberikan bimbingan dengan menggunakan Berita Acara Serah Terima Formulir APC-11 disertai risalah singkat pembinaannya;

4. Bimbingan terhadap narapidana sebagaimana dimaksudkan dalam huruf e dilaksanakan oleh Balai Bimbingan Kemasyarakatan dan Pengentasan Anak melalui program bimbingan dengan memperhatikan pertimbangan Tim Pengamat Pemasyarakatan (TPP) Balai Bimbingan Kemasyarakatan dan Pengentasan Anak.

Bagi narapidana yang ikut bimbingan dan pembinaan harus memenuhi persyaratan yang telah ditetapkan dalam Peraturan pemerintah Nomor 32 Tahun 1999 tentang Syarat Dan Tata Cara Pelaksanaan Hak Warga Binaan Pemasyarakatan. Pasal 11 menyatakan bahwa tata cara untuk pemberian Asimilasi, Pembebasan Bersyarat, Cuti Menjelang Bebas atau Cuti Bersyarat sebagaimana dimaksud dalam Pasal 10 adalah sebagai berikut .34

a. Tim Pengamat Pemasyarakatan (TPP) LAPAS atau TPP RUTAN setelah mendengar pendapat anggota TPP dan mempelajari laporan perkembangan pembinaan dari Wali Pemasyarakatan, mengusulkan pemberian Asimilasi, Pembebasan Bersyarat, Cuti

34 Gatot Supramono, Hukum Narkoba Indonesia, Edisi Revisi, Cet.4, Djambatan, 2009, Jakarta, hlm.24
Menjelang Bebas atau Cuti Bersyarat kepada Kepala LAPAS atau Kepala RUTAN;

b. Untuk Asimilasi, apabila Kepala LAPAS atau Kepala RUTAN menyetujui usul TPP LAPAS atau TPP RUTAN selanjutnya menerbitkan keputusan Asimilasi;

c. Untuk Cuti Menjelang Bebas atau Cuti Bersyarat, apabila Kepala LAPAS menyetujui usul TPP LAPAS atau TPP RUTAN selanjutnya meneruskan usul tersebut kepada Kepala Kantor Wilayah Departemen Hukum dan Hak Asasi Manusia setempat;

d. Untuk Pembebasan Bersyarat, apabila Kepala LAPAS atau Kepala RUTAN menyetujui usul TPP LAPAS atau TPP RUTAN selanjutnya meneruskan usul tersebut kepada Kepala Kantor Wilayah

Departemen Hukum dan Hak Asasi Manusia setempat, dengan tembusan kepada Direktur Jenderal Pemasyarakatan;

e. Kepala Kantor Wilayah Departemen Hukum dan Hak Asasi Manusia dapat menolak atau menyetujui tentang usul Cuti Menjelang Bebas, Cuti Bersyarat, atau Pembebasan Bersyarat setelah mempertimbangkan hasil sidang TPP Kantor Wilayah Departemen Hukum dan Hak Asasi Manusia setempat;

f. Apabila Kepala Kantor Wilayah Departemen Hukum dan Hak Asasi Manusia menolak tentang usul Cuti Menjelang Bebas, Cuti Bersyarat, atau Pembebasan Bersyarat, maka dalam jangka waktu paling lama 14 (empat belas) hari terhitung sejak diterimanya usul tersebut memberitahukan penolakan itu 
beserta alasannya kepada Kepala LAPAS atau Kepala RUTAN;

g. Apabila Kepala Kantor Wilayah Departemen Hukum dan Hak Asasi Manusia menyetujui tentang usul Cuti Menjelang Bebas atau Cuti Bersyarat maka Kepala Kantor Wilayah Departemen Hukum dan Hak Asasi Manusia menerbitkan keputusan tentang Cuti Menjelang Bebas atau Cuti Bersyarat;

h. Apabila Kepala Kantor Wilayah Departemen Hukum dan Hak Asasi Manusia menyetujui tentang usul Pembebasan Bersyarat maka dalam jangka waktu paling lama 14 (empat belas) hari terhitung sejak diterimanya usul tersebut meneruskan usul kepada Direktur Jenderal Pemasyarakatan;

i. Apabila Direktur Jenderal Pemasyarakatan menolak tentang usul Pembebasan Bersyarat, maka dalam jangka waktu paling lama 14 (empat belas) hari terhitung sejak tanggal penetapan memberitahukan penolakan itu beserta alasannya kepada Kepala LAPAS atau Kepala RUTAN; dan

j. Apabila Direktur Jenderal Pemasyarakatan menyetujui tentang usul Pembebasan Bersyarat, maka Direktur Jenderal Pemasyarakatan menerbitkan keputusan tentang Pembebasan Bersyarat.

Jumlah keseluruhan Narapidana yang menjadi binaan Bapas sekarisidenan Pati ada 500 orang yang terbagi di Rutan Blora, Rutan Rembang, Lapas Pati, Rutan Kudus, Rutan Demak dan Rutan Jepara. Peran Bapas sangat strategis dalam membina dan membimbing narapidana, karena Bapas mempunyai tanggung jawab yang besar, yaitu mendidik dan membina narapidana untuk menjadi pribadi yang lebih baik dan dapat diterima kembali di tengah-tengah masyarakat.

\section{Kendala-Kendala Yang Muncul Dalam Melakukan Bimbingan Terhadap Klien Narkoba Di Balai Pemasyarakatan (BAPAS) Pati}

Dalam melaksanakan program pembinaan dan bimbingan terhadap narapidana klien narkoba tidak terlepas dari hambatan atau kendala-kendala yang muncul. Kendala atau hambatan yang dihadapi Bapas Pati dalam pelaksanaan pembinaan dan bimbingan terhadap klien narkoba yaitu sebagai berikut $:^{35}$

a. Terbatasnya petugas di Bapas Pati

Petugas yang bekerja di Balai Pemasyarakatan Pati jumlahnya sangat terbatas yaitu hanya 18 orang, apabila dibandingkan dengan 2017 jumlah pegawai di Balai Pemasyarakatan Pati hanya 17 orang dengan sumber daya manusia yang sangat terbatas.

b. Minimnya Anggaran

Minimnya anggaran biaya yang dianggarkan oleh Bapas Pati tidak terlepas dari anggaran biaya dari pusat yang telah ditentukan jumlahnya, hal ini tidak sesuai dengan anggaran program yang sudah disusun oleh Bapas Pati, sehingga program dengan prioritas utama yang dilaksanakan oleh Bapas Pati. Jumlah anggaran untuk Bapas Pati juga tidak seimbang dengan wilayah kerja Bapas Pati yang cukup luas. Anggaran 2016 adalah sebesar Rp.60.000.000,- (enam puluh juta rupiah), dengan perincian untuk Pendampingan Diversi sebesar Rp.15.000.000,- (lima belas juta rupiah), Pendampingan Sidang Anak

\footnotetext{
${ }^{35}$ Bambang Sulistyo, wawancara pribadi, Kasubsi Bimbingan Klien Dewasa Bapas Pati, tanggal 15 Agustus 2018
} 
sebesar Rp.25. 000.000,- (dua puluh lima juta rupiah), sedangkan untuk Pendampingan Klien sebesar Rp.10.000.000,- (sepuluh juta rupiah) dan untuk biaya program Bimbingan Kemandirian sebesar Rp.10.000.000,(sepuluh juta rupiah). Berdasarkan anggaran sebagaimana tersebut dalam tabel di atas jelas sangat minim untuk sebuah program pembinaan dan bimbingan terhadap klien di Bapas Pati.

c. Masih adanya klien yang kurang bersungguh-sungguh dalam mengikuti pembimbingan dan pembinaan

Dalam sebuah kegiatan pasti ada yang bersemangat mengikuti dan ada pula yang tidak berminat atau hanya sebagai formalitas saja dalam mengikuti kegiatan, bagitu juga dengan pembimbingan dan pembinaan yang dilaksanakan oleh Bapas Pati terhadap klien narkoba, namun demikian program tetap jalan terus. Kesadaran dan niat dari klien memang sangat berperan dalam mengikuti program pembimbingan dan pembinaan.

d. Sarana dan prasarana di Bapas Pati

Sarana dan prasarana di Bapas Pati yang tergolong masih minim, khususnya fasilitas untuk latihan dan praktik kerja lapangan. Peralatan yang dibutuhkan untuk menunjang kinerja warga binaan masih kurang lengkap. Belum adanya wadah yang menjadi penampung dan pemasaran hasil dari keterampilan yang dihasilkan dalam bimbingan keterampilan dalam bentuk barang maupun jasa.

\section{Konsep Pembimbingan Yang Baik Bagi Klien Narkoba Di Masa Mendatang}

Penerapan konsep bimbingan untuk masa yang akan datang khususnya bagi klien warga binaan pada umumnya dan klien warga binaan kasus narkoba pada khususnya yaitu dengan membimbing warga binaan dari awal, yaitu dari sejak warga binaan masuk ke Rutan atau Lapas. Karena selama ini pembimbingan dan pembinaan yang dilakukan oleh Bapas hanya pada klien yang Menjelang Pembebasan Bersyarat, Cuti Menjelang Bebas dan Cuti Bersyarat, sebagaimana diatur pada Pasal 16 Peraturan Menteri Hukum Dan Hak Asasi Manusia Republik Inoonesia Nomor M.2.Pk.04-10 Tahun 2007 tentang Syarat Dan Tata Cara Pelaksanaan Asimilasi, Pembebasan Bersyarat, Cuti Menjelang Bebas, Dan Cuti Bersyarat. ${ }^{36}$

Dalam melaksanakan program pembimbingan dan pembinaan dari awal perlu payung hukum yang mengaturnya, maka perlu adanya Peraturan Menteri Hukum dan HAM yang baru, mengingat Peraturan Menteri dan HAM yang berlaku sekarang ini yaitu Peraturan Menteri Hukum Dan Hak Asasi Manusia Republik Inoonesia Nomor M.2.Pk.04-10 Tahun 2007 tentang Syarat Dan Tata Cara Pelaksanaan Asimilasi, Pembebasan Bersyarat, Cuti Menjelang Bebas, Dan Cuti Bersyarat, produk peraturan tersebut perlu adanya perubahan dan bila mana perlu diganti dengan Peraturan Menteri yang baru disesuaikan dengan kondisi saat ini. ${ }^{37}$

\section{Kesimpulan}

Berdasarkan hasil penelitian dan pembahasan sebagaimana pada bab sebelumnya, maka dapat ditarik kesimpulan bahwa :

\footnotetext{
${ }^{36}$ Dwidja Priyanto, Sistem Pelaksanaan Pidana Penjara Di Indonesia, Refika Aditama, 2006, Bandung, hlm.27

${ }^{37}$ Bambang Waluyo, Pidana Dan Pemidanaa, Sinar Grafika, 2004, Jakarta, hlm.55
} 
1. Peran Balai Pemasyarakatan (BAPAS) Pati dalam membimbing dan pembinaan terhadap klien narkoba

Peran Bapas sangat strategis dalam membina dan membimbing narapidana, Bapas Pati dalam melaksanakan bimbingan dan pembinaan terhadap klien Narapidana Narkoba yang memperoleh Pembebasan Bersyarat, Cuti Menjelang Bebas, Cuti Bersyarat sebagaimana diatur Pasal 10 Keputusan Direktur Jendral Pemasyarakatan Nomor E.06-PK.04.10 Tahun 1992 Tentang Petunjuk Pelaksanaan Asimilasi, Pembebasan Bersyarat dan Cuti Menjelang Bebas.

2. Kendala-kendala yang muncul dalam melakukan bimbingan terhadap klien narkoba di Balai Pemasyarakatan (BAPAS) Pati

a. Terbatasnya petugas di Bapas Pati

b. Minimnya Anggaran

c. Masih adanya klien yang kurang bersungguh-sungguh dalam menguikuti pembimbingan dan pembinaan

d. Sarana dan prasarana di Bapas Pati

3. Konsep pembimbingan yang baik bagi klien narkoba di masa mendatang

Penerapan konsep bimbingan untuk masa yang akan datang khususnya bagi klien warga binaan pada umumnya dan klien warga binaan kasus narkoba pada khususnya yaitu dengan membimbing warga binaan dari awal, yaitu dari sejak warga binaan masuk ke Rutan atau Lapas.

\section{Saran}

Berdasarkan kesimpulan di atas, maka penulis memberikan saran sebagai berikut :
1. Diharapkan adanya kegiatan mengenai pembinaan narapidana bagi para pembimbing di Bapas agar pembinaan yang dilakukan terhadap narapidana bisa lebih efektif dan berpengaruh besar pada kemandirian narapidana.

2. Penyediaan sarana dan prasana yang memadai yang dapat menunjang katerlaksanaan dan tersuksesanya kegiatan bimbingan karier terhadap narapidana.

3. Bapas Pati dapat menambah tenaga petugas untuk menunjang kelancaran dalam memberikan pembinaan dan bimbingan kepada narapidana khususnya klien narkoba.

4. Untuk kegiatan pembinaan kemandirian atau ketrampilan lebih diperbanyak lagi agar narapidana yang belum minat dan tidak sesuai dengan bidangnya dapat ikut serta dalam kegiatan pembinaan tersebut.

\section{DAFTAR PUSTAKA}

Abdul Djamali, 1990, Pengantar Hukum Indonesia, Raja Grafindo Persada, Jakarta

Andi Hamzah, 2008, Asas Asas Hukum Pidana, Rineka Cipta, Jakarta

Bambang Sunggono, 2013, Metodologi Penelitian Hukum Cetakan ke-14, Rajawali Pers, Jakarta

Bambang Waluyo, 2004, Pidana Dan Pemidanaan, Sinar Grafika, Jakarta

Dyah Ochtorina Susanti dan A'an Efendi, 2014, Penelitian Hukum 
(Legal Research), Sinar Grafika, Jakarta.

Dwidja Priyanto, 2006, Sistem Pelaksanaan Pidana Penjara Di Indonesia, Refika Aditama, Bandung.

Gatot Supramono, 2009, Hukum Narkoba Indonesia, Edisi Revisi, Cet.4, Djambatan, Jakarta

H. Zainuddin Ali, 2010, Metode Penelitian hukum, Sinar Grafika, Jakarta

\section{Perundang Undangan}

Undang-Undang Dasar Negara Republik Indonesia Tahun 1945

Undang-Undang Nomor 12 Tahun 1995 tentang Pemasyarakatan

Undang-Undang RI Nomor 35 Tahun 2009 tentang narkotika dan Undang-Undang Nomor 5 tahun 1997 tentang Psikotropika

Peraturan Pemerintah Nomor 28 Tahun 2006 tentang Perubahan Atas Peraturan Pemerintah Nomor 32 Tahun 1999 tentang Syarat dan Tata Cara Pelaksanaan Hak Warga Binaan. 